\title{
VARIABEL
}

e-ISSN: 2593-302X dan p-ISSN: 2599-3038

This work is licensed under

a Creative Commons Attribution-NonCommercial 4.0 International License.

\section{Mathematical Learning with Metacognitive Ability Based on Problems in Solving the Source of Mathematical Stories in SMP Patra Dharma 2 Balikpapan}

\author{
Rahayu Sri Waskitoningtyas \\ FKIP of Balikpapan University, Balikpapan, Indonesia \\ rahayu.sri@uniba-bpn.ac.id
}

\section{Keywords :}

math story problem, metacognition ability, problem solving

\begin{abstract}
This study aims to describe the learning of mathematics with metacognitive ability based on problem solving in solving mathematics story problem in SMP Patra Dharma 2 Balikpapan. The type of this research is qualitative research, while the sampling technique is purposive sample. The results showed that through solving problems in solving mathematical problems, (1) learners will be trained to always involve metacognitive skills from the beginning of solving the problem of mathematics to the end of the form of formulation of answers and evaluate the results of work, (2) learners who have good metacognition skills tend to solve problems of solving problems of mathematical stories that they face well through the mobilization of consciousness and contextual thinking arrangements, and (3) learners are required to mobilize awareness and regulation of thinking (metacognition) through some math problem solving exercise.
\end{abstract}

\section{INTRODUCTION}

Implementation of education in Indonesia is an effort to form the next generation of noble people who have the knowledge and noble personality that contains the meaning of national character rooted in the 1945 Constitution and Pancasila philosophy (Anas, 2013:41).

Implementation of education through teaching and learning process is basically the core of education as a whole, where teachers play an important role in the learning process. The teacher is an educator who is directly involved in teaching and learning process in charge of creating learning conditions that can make learners learn optimally to get the desired learning achievement. A teacher should strive for active learners in the learning process by using appropriate learning strategies.

Potential learners can be developed with the atmosphere of learning. The process of learning that is in school is very important to improve learning outcomes of learners. Teaching and learning process will not run well without any learning process. Many lesson materials that learners should learn, start to learn to speak, count, and so forth. 
Learning is very important for learners from elementary school to higher levels. With the learning of learners are able to learn things from start counting, reading, writing, listening, to the stage of solving a problem. Changes in behavior in the form of knowledge, attitude, and skills is called learning. This change is settled in behavior that occurs as a result of practice or experience. Learning is basically an educator effort to help learners in carrying out learning activities, in order to achieve satisfactory learning outcomes (Isjoni, 2009:25).

To improve the quality of education, the curriculum was established. The curriculum is closely related to the metacognitive ability of learners. Metacognitive ability is an ability to understand and determine a person's cognitive activity in the learning process (Muijs \& Reynold, 2011). With metacognitive ability, learners can know how to learn and learn, know the ability and learning modalities possessed and know the best learning strategies for effective learning.

Some examples of celebrations associated with the cognition process are everything that happens and can be used as evidence among others: (1) Do you know the victim? (2) Since when did you know the victim? (3) When did you meet before the victim died? (4) What did you do during the meeting? (5) Do you hate the victim, ... and so on. The police also went on to ask questions such as (6) To what extent do you know the victims? (7) After a long time does not meet how you feel when meeting the victim at the cafe? (8) Why did you decide on the cafe as a meeting place, (9) Why you ordered food and drinks.

From these examples we can see the difference in answers to questions 1-5 with questions 6-9. Answers to questions No. 1-5 provide information about data or alibis (exposed externally) from suspects that can be validated. But for the 6-9 questions the answer to that question is more or less ours to get as much information as to what the suspect thinks that only the relevant person knows (internal), the answer provides information that reveals the cause or reason of the alibi obtained from question no 1-5. By linking information obtained both externally and internally, the police obtain complete information so that the police can determine that the suspect is an actual killer. Questions 1-5 are examples of the cognition process and questions 6-9 are examples of metacognition processes.

The definition of metacognition is knowledge, awareness, and self-control. Thus, metacognitive development can be described as a development of a person's metacognitive ability, which leads to greater knowledge, awareness and control of a person's learning (Baird in Feriyal Cubuku, 2008:1).

There are several factors that have not been optimal cognitive activity of learners in learning mathematics. Among them is that in learning mathematics, learners are always directed to memorize the information as much as possible then used in solving problems related in mathematics. From the reality in the field, few learners are really able to remind the information related to mathematics learning because of the low absorption of learners.

The low absorption of learners is due to the condition of learning that is still conventional and does not touch the realm of the learner's dimension itself, that is how it actually learns it (learn to learn). In a more substantial sense, that learning process to adulthood still gives teacher dominance and not enough to provide access for learners to develop independently through discovery and thought processes. In addition to this during the learning of mathematics, learners are almost never required to try other ways and strategies in solving problems.

Efforts are made to overcome the above problems is to implement a learning strategy that is able to expand the skills of learners in solving problems and intensify their cognitive abilities. One appropriate strategy is metacognitive strategies.

This research refers to research Nurasyiyah (2014) background because less learning that involve awareness of thinking. So that the learning takes place becomes less meaningful. This causes the achievement of the mathematical ability of learners has not fulfilled the minimum learning mastery expected level. Among the abilities that are still lacking is the ability to connect and solve 
mathematical problems. The purpose of Nurasyiyah's research is to know the achievement obtained by learners in connection ability and problem solving of mathematics after doing the learning with metacognitive approach, and how the learners response to this learning.

Based on the journal written by Amelia, Musdi, and Amalita (2014) shows that the results and discussion as follows: (1) on the application of metacognitive strategy in class XI IPA 1 SMA Negeri 3 Padang encourages learners to be more active during learning so that activity learners tend to increase and (2) learning mathematics with metacognitive strategies in class XI IPA 1 SMA Negeri 3 Padang during the study has increased for each indicator under study.

\section{METHOD}

This research was conducted in SMP Patra Dharma 2 Balikpapan in class VIII A amounted to 30 students, which was held in odd semester on November 30, 2017.

This research approach using qualitative approach. According Sugiyono (2011: 15), qualitative research is used to examine the natural object condition, where the researcher is as the key instrument, the sampling of data source is done by purposive sampling, collecting technique with triangulation (combination), data analysis is inductive/qualitative, and qualitative research results emphasize more meaning than generalization.

Judging from the type of research, this study includes field research, because this study intensive study of the current state of the environment and the environmental interaction of a social unit, group, institution and community implemented in life and reality sebanarnya.

Data collection methods required in this study are questionnaire, observation, written test or observation, documentation, triangulation.

Data analysis techniques used in this study is to use the steps as proposed by Bungin (2003: 70), as follows: (a) data collection, (b) data reduction, (c) display data and (d) verification and affirmation of Conclusions

\section{RESULTS AND DISCUSSIONS}

This metacognition activity data is derived from the problem solving process carried out with the problem solving learning model, combined with the results of written work, and interviews. Troubleshooting is done for the following issues:

A learner wants to calculate the area of the rectangle, if known The circumference of a rectangle is 102 $\mathrm{cm}$ and the length of a rectangle is $12 \mathrm{~cm}$ larger than its width. Firstly students should write a rectangular circumference formula that is circular $=2(\mathrm{p}+1)$ and $\mathrm{p}=12+1$. Then enter the length of the rectangle into the formula around the rectangle.

In the case of number 1 participants difficulties where the length, because learners are familiar with the problem with a direct rectangle number, and calculate the area of the rectangle by multiplying the length and width of the already known value. As for the number 1, it must first find the width value of the rectangle by entering the equation of the rectangle length to the circumferential formula. After obtaining the value of the rectangle width then learners look for the value of the rectangle length. After the rectangular and rectangular values are obtained then learners calculate the area of the rectangle.

In the problem-solving process, the subject has involved a fairly complete metacognition activity that may be by drawing a rectangle, then placing the equation of the rectangular width. After the value of the length and width of the rectangle is obtained, the value of the length and width of the rectangle is placed in the rectangular image. Metacognition activities include planning, monitoring and reflection. One stage that does not involve a full range of metacognition activities is the stage of creating a plan 
of resolution, ie not involving the type of monitoring and reflection activity. Based on the results of the interview, the metacognition activity is not complete because the actual subject has been convinced that the thought process is right, because it is supported by the involvement of complete metacognition activities in the previous and subsequent splitting stages.

On the number two concerning the age of the father and the age of the mother is 60 years and the difference in their age is 4 years (older father). Determine the age of the father and the age of the mother. First the learner must assume $\mathrm{x}$ is the age of the father while $\mathrm{y}$ is the age of the mother. With $\mathrm{x}$ $+y=60$ and $x-y=4$. Then learners may work with substitution, elimination or mix.

Learners can do the second number with an approximation. That the age of the father is much older than the mother with a difference of 4 years, and when added the age of father and mother is 60 years.

On the number three problem is a ship sailing northward as far as $11 \mathrm{~km}$. Then, the ship turned westward and sailed as far as $9 \mathrm{~km}$. Students first draw, by way of making a line to the north as far as 11 units, then turn left 9 units. After that the students look for the hypotenuse value.

Learners accustomed to calculate hypotenuse with already know the value of the base and the height of the right triangle. Sometimes learners have difficulties in understanding the story of problem number three. To understand the number three, learners first draw. Then calculate the hypotenuse by finding the summing root of the squares of 11 and the squares of 9. Learners also need not by drawing a right triangle, perhaps in a direct way that is the square of 11 and the square of 9 , then summed.

Through the solution of mathematical problems in solving the story problem, it seems clear that the implementation of a series of metacognition activities during the process shows a good state. The situation can be seen in the complete type of metacognition activity that is done, and the high frequency of implementation of some metacognition activities. This leads to a problem-solving situation that is done very well, i.e. every step of the solution is always based on awareness and arrangement of thought processes. Further discussion is done at each stage of the solution.

1. Stage to understand the problem. Troubleshooting begins with an attempt to understand the problem. Since the beginning of this stage, the subject has shown his awareness of his thinking process on the problem to be solved by performing metacognition activities setting goals (P1), and plotting a specific representation to support understanding (P4). These two metacognition activities have become the basis for establishing a clear direction for the subsequent solution process. The stage of understanding this problem is followed by the involvement of metacognition activities that control the terminology/notation (M1) to ensure that the intent to understand the problem can be achieved. Subsequently the subject controls the development of self-knowledge by reflecting through metacognition activities i.e. reflection on concepts (R1), structural analysis of mathematical expressions (R3), and deliberate choice of a representation to support understanding (R5). With all metacognition activities, it can be interpreted that the implementation of the stage of understanding the problem by the subject, is done by involving awareness of knowledge and thought processes that must be developed, and can arrange it to be able to understand the problem.

2. The next step is to plan the solution. The implementation of this stage has involved some metacognition activities included in the planning group. The metacognition activity is planning a representation (P4) and setting up a breaking strategy (P2). These two metacognition activities take place several times, indicating the strong involvement of the subject's awareness of his knowledge in each plan of solution. At this stage the subject does not perform metacognition activities of the type of monitoring and reflection. But based on the results of the analysis, it is clear that the control of the steps of planning and monitoring the development of thinking in the determination of a strategy to ensure the correct plan is appropriate, has implicitly done subject, when carrying out other metacognition activities. One example that can be used in this regard is the following interview result:

P: For question number 1 is the circumference of a rectangle 102. If the length of a rectangle is 12 $\mathrm{cm}$ larger than the width. Determine the length and width of a rectangle, then calculate the area. How do you get started doing it? 
$\mathrm{N}$ : Written length and width of rectangle, but I am still confused with question number 1 because the length and width is not yet known.

P: Keep the right way to work

$\mathrm{N}$ : I am still confused with the length of the rectangle of the book. This is 12 times longer than its width. Whereas known only Round around the rectangle

Q: Why confused with the problem, if the length of a rectangle is 12 times longer than its width?

$\mathrm{N}$ : How do you do it?

P: Previously mother had given example of this problem, try to see your note.

N: Ohh. I remember.

P: By way of substitution, that is, the equation of the rectangle length is $12+l$ is substituted for the circumference of the rectangle.

$\mathrm{N}$ : This is like this.

$102=2(p+12+l)$

P: Yes.

3. The next stage is to implement the plan of solution. When observed metacognitive activity that executed with the most frequent frequency, it is seen that the frequency of the highest activity of metacognition is in the group of reflection activity. Metacognition activities that are accomplished are reflections on concepts (R1), awareness of application/strategy use (R2), structural analysis of mathematical expressions (R3), and deliberate choice of a representation to support understanding (R5). This suggests that during the execution of the solution plan, the subject is sufficiently intensive to monitor the development of his or her knowledge to ensure that the strategy of the solution is appropriate. Besides, the subjects also perform metacognition activities in the monitoring group with quite a lot of frequency. Metacognition activity is done to control the terminology/notation (M1) and control the calculation accuracy (M3). It also indicates that the subject executes the plan of resolution by constantly evaluating the results to ensure that the established plan has been achieved. In addition the subject also performs metacognition activities establishing intermediate results that can be achieved (P3). This activity is related to the awareness of the subject towards the achievement of the goal.

4. The final stage is the evaluation phase of the solution. This stage is carried out by involving some metacognition activities. The metacognitive activity that is accomplished is to establish intermediate achievable results (P3), control what is considered error (M2), control argument (M4), deliberate choice of a representation to support understanding (R5), and analysis of decision structure taken (R4). The implementation of all metacognition activities indicates that the implementation of the evaluation phase of the solution is done by involving the subject's awareness of his knowledge, controlling the results obtained to ensure the achievement of the objectives of the solution, and monitoring the development of self-knowledge to ensure that the choice of dispute strategy is appropriate. One example that can be related to the subject's awareness of his thinking process during the execution of the evaluation phase of the solution is presented in the results of the interview below.

Q: How to solve the problem for question number 2 about the age of the father and the age of the mother is 60 years and the difference in their age is 4 years (older father). Determine the age of the father and the age of the mother?

$\mathrm{N}$ : Little, let us suppose $x$ is the age of father and $y$ is the age of the mother.

$\mathrm{P}$ : Yes, keep going

$\mathrm{N}: x+y=60$ and $x-y=4$.

P: Yes.

$\mathrm{N}$ : Work by elimination or substitution or mix book.

Q: Whatever, do what you think is the easiest.

$\mathrm{N}$ : O.K miss. Keep going for number 3 .

P: Problem number three A ship sailed northward as far as $11 \mathrm{~km}$. Then, the ship turned westward and sailed as far as $9 \mathrm{~km}$. Determine the distance from the start point of departure to the end point.

N: Confused book.

P: Let's draw it first.

$\mathrm{N}$ : ehh. 
P: Drawing, there is the north word up or down.

N: Go to the top of the book.

P: Continue word west $9 \mathrm{~km}$.

$\mathrm{N}$ : To the left of the book.

Q: Continue to build what is it?

$\mathrm{N}$ : Triangle.

Q: To calculate the hypotenuse how?

$\mathrm{N}: 112+92$

$\mathrm{P}$ : it's not right.

$\mathrm{N}: 112+92$ is then rooted.

P: Yes

5. From the results of questionnaires acquisition process of learning by mathematics teacher filled by learners obtained that: (1) preparation of learning mathematics teacher equal to $90 \%$, (2) mathematics learning process equal to $81 \%$, (3) evaluation/appraisal of mathematics equal to $83 \%$, and (4) personality and social math teacher by $91 \%$. While the questionnaire preparation of mathematics learning by mathematics teachers filled by learners by $86 \%$.

\section{CONCLUSION AND SUGGESTION}

Based on the above troubleshooting process, it can be concluded: through solving problems in solving mathematical problems, subjects will be trained to always involve their metacognitive skills from the beginning of problem solving to the final part of the formulation of answers as well as evaluating to ensure the achievement of goals related to the contextual situation of the problem solved. Learners who have good metacognition skills tend to solve the problems they face well through the mobilization of consciousness and the arrangement of thinking they are doing. In solving mathematical problems in solving math story problems, learners are required to be able to mobilize awareness and regulation of thinking (metacognition), so it can be said that learners will experience the exercise of mobilizing metacognition ability. So by familiarizing the learners involved in solving mathematical problems in solving the problem of mathematical stories, it will occur the process of completion of metacognition ability of learners. The acquisition of the learning process questionnaire by the mathematics teacher filled by the students found that: (1) preparation of learning mathematics teacher $90 \%$, (2) mathematics learning process $81 \%$, (3) evaluation/appraisal of mathematics learning equal to $83 \%$ and (4) the personality and social teacher of mathematics $91 \%$. While the questionnaire preparation of mathematics learning by mathematics teachers filled by learners by $86 \%$.

Some of the students' work.

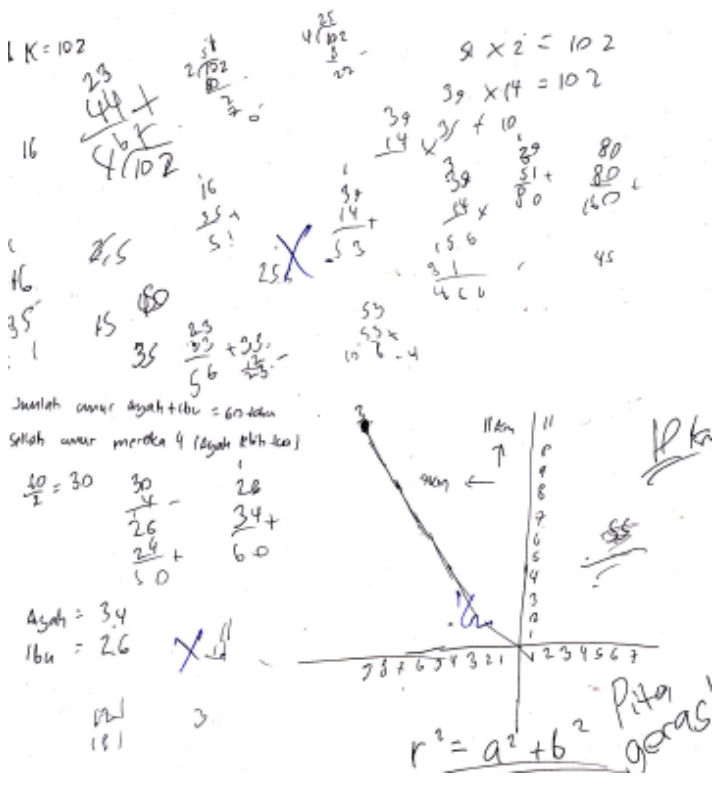

Fig 1. Students Only Do Questions 1 and 2 


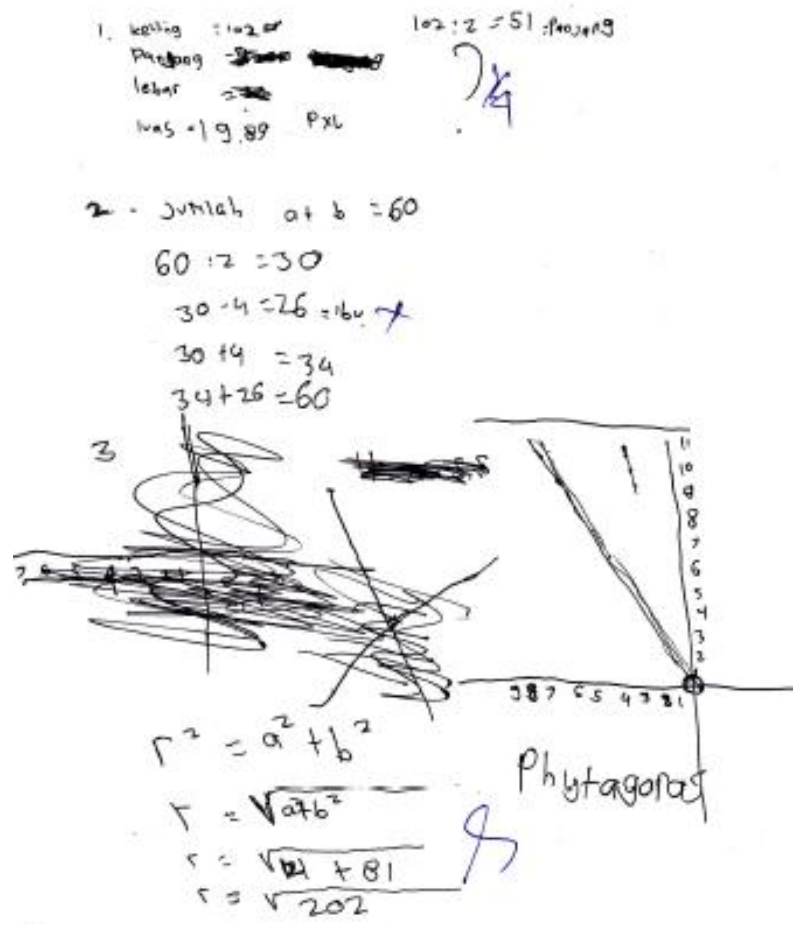

Fig 2. Students Working on Questions 1, 2 and 3 but Numbers 1 and 2 are Less than Perfect

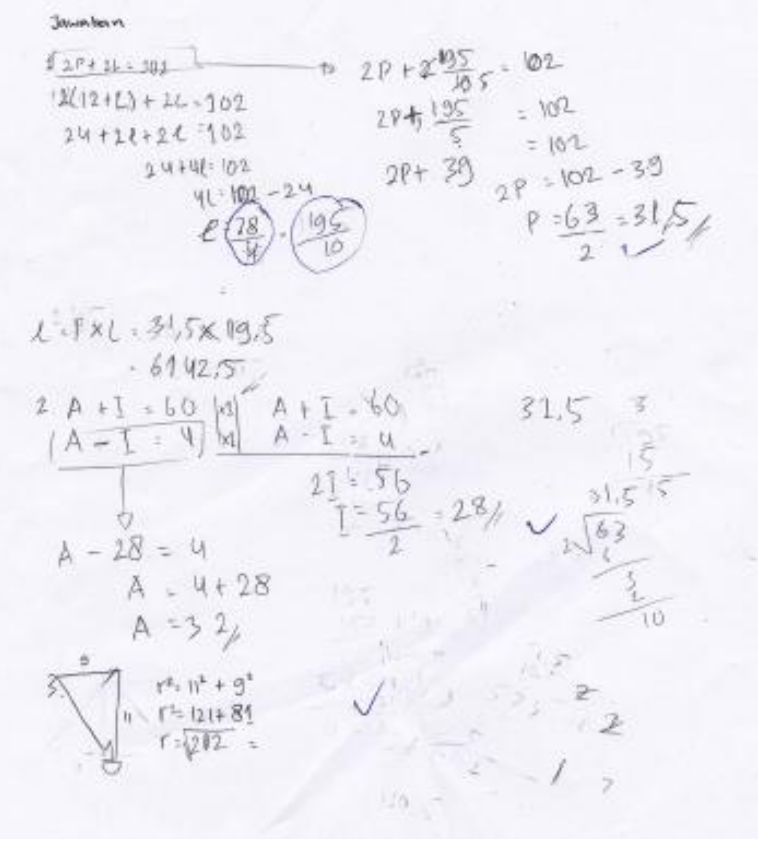

Fig 3. Student's Answer Correct

\section{REFERENCES}

Amelia,V., Musdi, E., \& Amalita, N. (2014). Penerapan Strategi Metakognitif Untuk Meningkatkan Kemampuan Penalaran Matematis Siswa Kelas XI IPA 1 SMA Negeri 3 Padang. Jurnal Pendidikan Matematika, 3(1), 51-55. 
Anggo, M. (2010). Proses Metakognisi Mahapeserta didik Calon Guru dalam Pemecahan Masalah Matematika. Disertasi S3. Surabaya: Pendidikan Matematika PPs Universitas Negeri Surabaya. (Unpublished).

Anggo, M. (2011). Pemecahan Masalah Matematika Kontekstual untuk Meningkatkan Kemampuan Metakognitif Peserta didik. Edumatica, 1(2). ISSN 2088-2157.

De Corte, E. (2003). Intervention Research: A Tool for Bridging the Theory-Practice Gap in Mathematics Education. Proceedings of the International Conference, The Mathematics Education into the 21st Century Project, Brno Czech Republic.

Dimyati \& Mudjiono. (2013). Belajar dan Pembelajaran. Jakarta: Rineka Cipta.

Gama, C. A. (2004). Integrating Metacognition Instruction in Interactive Learning Environment. D. Phil Dissertation. University of Sussex. (Unpublished).

Isjoni. 2010. Pembelajaran Kooperatif Meningkatkan Kecerdasan Komunikasi Antar Peserta Didik. Yogyakarta: Pustaka Pelajar.

Johnson, E. B. (2002). Contextual Teaching and Learning; What It is and Why It's Here to Stay. California: Corwin Press Inc.

Kuntjojo \& Matulessy, Andik. (2012). Hubungan antara Metakognisi dan Motivasi Berprestasi dengan Kreativitas. Jurnal Persona, 1(1).

Mousoulides, N., Christou, C., \& Sriraman, B. (2007). From Problem Solving to Modelling- A Meta Analysis. University of Cyprus.

Muisman. (2002). Analisis Jalur Hasil Belajar Mata Pelajaran Ekonomi Berdasarkan Kecerdasan Strategi-strategi Metakognitif dan Pengetahuan Awal. Singaraja: IKIP Singaraja.

Mujis, D., \& Reynolds, D. (2011). Effective Teaching: Evidence and Practice $3^{\text {rd }}$ Edition. Chippenham: CPI Antony Rowe.

Nanang. (2009). Studi Perbandingan Kemampuan Pemahaman dan Pemecahan Masalah Matematika pada Kelompok Peserta didik yang Pembelajarannya Menggunakan Pendekatan Kontekstual dan Metakognitif serta Konvensional. Disertasi. Bandung: SPs UPI Bandung. (Unpublished).

Nelissen. (1997). Thinking Skill in Realistic Mathematics. (Download tanggal 12 September 2006).

Nurasyiyah, D. A. (2014). Pendekatan Metakognitif dalam Pembelajaran Matematika untuk Pencapaian Kemampuan Koneksi Data Pemecahan Masalah Matematik Siswa SMA. JPM, 6(2), $115-125$

Polya, G. (1973). How To Solve It, Second Edition. New Jersey, Princeton: Princeton University Press.

Risnanosanti. (2008). Kemampuan Metkognitif Peserta didik dalam Pembelajaran Matematika. Jurnal Matematika dan Pendidikan matematika, 4(1). ISSN: 1978-4538.

Salahudin, A., \& Alkriencichie, I. (2013). Pendidikan Karakter Pendidikan Berbasis Agama dan Budaya Bangsa. Bandung: CV Pustaka Setia.

Santrock, J. W. (2008). Psikologi Pendidikan. Jakarta: Kencana.

Scanlon, D. (2012). Fact Sheet: Metacognitive Processes. https://teal.ed.gov/tealguide/metacognitive. (Diambil pada tanggal 20 Maret 2015).

Schoenfeld, A. (1987). Metacognition Learning and Mathematics. [Online]. Tersedia. http//mathforum.org/ sarah/Discussion. Sessions/shoenfeld.html. (21 maret 2016).

Solso, R. L., Otto, H. M., \& M.Kimberly, M. (2007). Psikologi Kognitif Edisi ke-delapan. Jakarta: Erlangga.

Sugiyono. (2014). Memahami Penelitian Kualitatif. Bandung: Alfabeta. 
Supinah. (2008). Pembelajaran Matematika Sd dengan Pendekatan Kontekstual dalam Melaksanakan KTSP. Yogyakarta: Pusat Pengembangan dan Pemberdayaan pendidik dan Tenaga Kependidikan Matematika.

Suryadi, D. (2010). Teori, Paradigma, Prinsip dan Pendekatan Pembelajaran MIPA dalam Konteks Indonesia. Bandung: FPMIPA UPI.

Waskitoningtyas, R. S. (2015). Pembelajaran Matematika dengan Kemampuan Metakognitif Berbasis Pemecahan Masalah Kontekstual Mahasiswa Pendidikan Matematika Universitas Balikpapan. Math Didactic Jurnal Pendidikan Matematika, 1(3), 211-219. 